\title{
Electrical requirements of defibrillation
}

Sir,

In the November issue of the British Heart fournal in an editorial, Adgey (1978) discussed the subject of electrical requirements of ventricular defibrillation, and the controversy that exists about this subject. Almost all data are in agreement except those of the Purdue workers, Geddes et al. (1974) and Tacker et al. (1974).

In an attempt to verify the Tacker data we developed an automatic defibrillation measuring system, which will be reported elsewhere, and obtained the data presented in the Fig. The patients all had an acute coronary infarction, primary ventricular fibrillation, thus fibrillation not associated with cardiac failure. The results show that the clinical data of Crampton et al., 1978 and Adgey et al., 1978, and ourselves all indicate that with stored energies of $200 \mathrm{~J}$ or less a substantial number of patients can be defibrillated. The energy requirement as suggested by Tacker et al. (1974) is very different.

Since all reported clinical data seem to fit it seems imperative to study the Tacker data itself.

As stated by Lown in a personal communication to Adgey, reanalysing the Tacker clinical data did not show significant influence of body weight on success or failure of defibrillation. Thus, Tacker et al. might have misinterpreted their own clinical data.

We analysed the animal data as presented by Geddes et al. (1974). They used five different experimental species. Eight rabbits ranging in weight from 2.3 to $3.4 \mathrm{~kg}, 11$ dogs 3.5 to $41 \mathrm{~kg}$, 4 goats 29 to $39 \mathrm{~kg}, 10$ ponies 80 to $193 \mathrm{~kg}$, and 2 horses 277 to $340 \mathrm{~kg}$.

It is unrealistic to assume that threshold data for those animals are comparable, for many reasons. One trivial reason is the fact that the shape of the thorax is different and therefore the distribution of the current in the thorax differs from species to species. Therefore the current density in the heart is different and also the threshold (Koning, 1972). For this reason we calculated from the Geddes data the power fit between current and energy, with respect to bodyweight for each species in the same

\begin{tabular}{|c|c|c|}
\hline Rabbits & $\begin{array}{l}I=0.46 \mathrm{~W}^{2 \cdot 14}(\mathrm{r}=0.51) \\
\mathrm{I}_{70}=4085 \mathrm{~A} \\
\mathrm{I}_{100}=8765 \mathrm{~A}\end{array}$ & $\begin{array}{l}\mathrm{U}=0.24 \mathrm{~W}^{\mathbf{2} \cdot 71}(\mathrm{r}=0.35) \\
\mathrm{U}=24,000 \mathrm{~J} \\
\mathrm{U}_{100}=63,000 \mathrm{~J}\end{array}$ \\
\hline Dogs & $\begin{array}{l}I=2.7 W^{0.64}(r=0.78) \\
I_{70}=41 \mathrm{~A} \\
I_{100}=51 \mathrm{~A}\end{array}$ & $\begin{array}{l}U=1.62 W^{1 \cdot 15}(\mathrm{r}=0.79) \\
U_{70}=214 \mathrm{~J} \\
U_{100}=323 \mathrm{~J}\end{array}$ \\
\hline Goats & $\begin{array}{l}I=0.74 W^{1.22}(r=0.56) \\
I_{70}=132 \mathrm{~A} \\
I_{100}=204 \mathrm{~A}\end{array}$ & $\begin{array}{l}\mathrm{U}=0.02 \mathrm{~W}^{2.64}(\mathrm{r}=0.58) \\
\mathrm{U}_{70}=1486 \mathrm{~J} \\
\mathrm{U}_{100}=3811 \mathrm{~J}\end{array}$ \\
\hline Ponies & $\begin{array}{l}I=8.27 W^{0.55}(r=0.55) \\
I_{70}=85 \mathrm{~A} \\
I_{100}=104 \mathrm{~A}\end{array}$ & $\begin{array}{l}\mathrm{U}=0.60 \mathrm{~W}^{1.56}(\mathrm{r}=0.65) \\
\mathrm{U}_{70}=453 \mathrm{~J} \\
\mathrm{U}_{100}=791 \mathrm{~J}\end{array}$ \\
\hline $\begin{array}{l}\text { Overall } \\
\text { (Geddes) }\end{array}$ & $\begin{array}{l}I=1.79 W^{0.88}(r=0.94) \\
I_{70}=75 \mathrm{~A} \\
I_{100}=103 \mathrm{~A}\end{array}$ & $\begin{array}{l}\mathrm{U}=0.89 \mathrm{~W}^{1 \cdot 48}(\mathrm{r}=0.94) \\
\mathrm{U}_{70}=479 \mathrm{~J} \\
\mathrm{U}_{100}=812 \mathrm{~J}\end{array}$ \\
\hline
\end{tabular}

$I=$ current strength, $U=$ energy, $W=$ bodyweight $(\mathrm{kg}), \mathbf{r}=$ correlation coefficient.

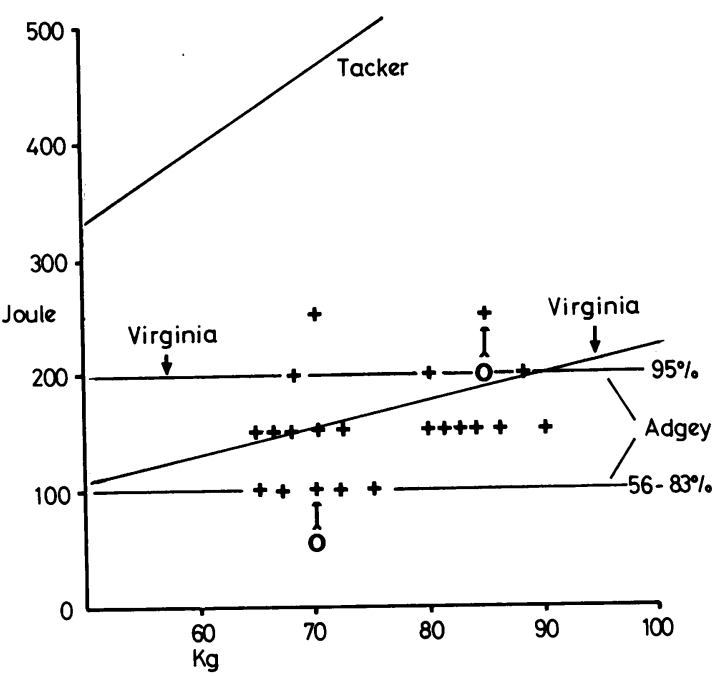

Fig. Energy levels for human defibrillation as a function of bodyweight. Both Adgey and Virginia data represent a percentage success with the used level of energy. $A$ successful event in our study is indicated with a plus and a failure with a zero. The dose suggested by Tacker et al. (1974) is also indicated. Data obtained in co-operation with Dr Nanninga, Department of Cardiology, Sittard, the Netherlands. The Virginia data as presented by the regression line are for 100 per cent success in the coronary patient. 
way as Geddes did for all species. From the computed relations we calculated the current and energy for a 70 and $100 \mathrm{~kg}$ subject of the same species (see Table).

Our conclusions from the recomputed Geddes animal data are:

(1) The different species all have different relations between energy and current with respect to body weight.

(2) Those relations are very weak because correlation coefficients ranged from 0.35 to 0.79 ; this makes extrapolation to higher bodyweight hazardous, and this is emphasised by the rabbit and goat data extrapolated to large weights.

(3) The difference in the mentioned relation between different species makes extrapolation to humans untenable.

(4) The clinical dose as recommended by Geddes and Tacker is based on weak experimental data. Therefore it seems logical that their dose differs from the actual one measured in clinical practice.

Finally we suggest that there need not be a controversy about defibrillation requirements, because the only conflicting data are based on weak grounds.

G. Koning,

Research and Development,

Cordis Europa N.V., P.O. Box 38,

9300 AA Roden,

The Netherlands.

R. Geuze and A. J. Meinema

Department Medical Physics,

Free University Amsterdam,

The Netherlands.

\section{References}

Adgey, A. A. J. (1978). Electrical energy requirements for ventricular defibrillation (editorial). British Heart fournal, 40, 1197-1199.

Adgey, A. A. J., Campbell, N. P. S., Webb, S. W., Kennedy A. L., and Pantridge, J. F. (1978). Transthoracic ventricular defibrillation in the adult. Medical Instrumentation, 12, 17-19.

Crampton, R. S., Gascho, J. A., Cherwek, M. L., Sipes, J. N., and Hunter, F. P. (1978). Low-energy and fast serial d.c. shock ventricular defibrillation in man (abstract). Medical Instrumentation, 12, 53.

Geddes, L. A., Tacker, W. A., Rosborough, J. P., Moore, A. G., and Cables, P. S. (1974). Electrical dose for ventricular defibrillation of large and small animals using precordial electrodes. Fournal of Clinical Investigation, 53, 310-319.

Koning, G. (1972). Some physical aspects of ventricular defibrillation. Ph.D. thesis, Free University Amsterdam.

Tacker, W. A., Galioto, F., Giuliani, E., Geddes, L. A., and McNamara, D. G. (1974). Energy dosage for human transchest defibrillation. New England fournal of Medicine, 290, 214-215. 